\title{
PELATIHAN UJI TOURNIQUET BAGI KADER KESEHATAN SEBAGAI SALAH SATU CARA DETEKSI DINI DEMAM BERDARAH DENGUE
}

\author{
Grace D. Kandou \\ Bagian Ilmu Kesehatan Masyarakat Fakultas Kedokteran Universitas Sam Ratulangi \\ Email: gracekandou@yahoo.com
}

\begin{abstract}
Dengue Haemorrhagic Fever (DHF) is still a communicable disease that sometimes becomes an epidemic in certain areas in Indonesia. Although health promotion and information about prevention and erradication of this disease have been carried out by various departments, this disease remains a horrifying one since it is fatal. Deaths due to Dengue Haemorrhagic Fever are mostly caused by the delay of lay people to recognize this disease in its early stages, and as a consequence, the patient is brought to the hospital too late. The aim of this study was to find out the level of knowledge of health providers about Dengue Haemorrhagic Fever and to train them to do a tourniquet test. Methods of educating were: through speeches, health promotion, and doing tourniquet simulations. Pre-tests showed that $64 \%$ of the participants still had a low level of knowledge about early signs and symptoms of Dengue Haemorrhagic Fever. Most participants did not know how to do the tourniquet test. After receiving information and doing simulation tourniquet tests there was a significant improvement of the participants' level of knowledge about Dengue Haemorrhagic Fever and early detection of this disease before referring the patients to hospitals.
\end{abstract}

Keywords: Dengue Haemorrhagic Fever, tourniquet test, health providers

\begin{abstract}
Abstrak: Penyakit demam berdarah Dengue (DBD) masih merupakan masalah penyakit menular yang kadangkala mewabah di beberapa daerah tertentu. Meskipun penyuluhan dan informasi tentang pencegahan dan pemberantasan penyakit menular demam berdarah Dengue telah sering dilakukan oleh Departemen terkait, namun penyakit ini masih merupakan penyakit yang ditakuti masyarakat karena dapat berakibat fatal yaitu kematian. Kematian akibat penyakit demam berdarah Dengue seringkali terjadi oleh karena keterlambatan masyarakat awam mengetahui diagnosis penyakit, sehingga penderita terlambat dibawa ke tempat pelayanan kesehatan (Rumah Sakit). Penelitian ini bertujuan untuk mengetahui pengetahuan kader kesehatan tentang demam berdarah Dengue serta memberikan pelatihan uji tourniquet kepada kader kesehatan. Metode kegiatan berupa ceramah, penyuluhan serta simulasi dan pelatihan. Hasil evaluasi awal (pre-test) menunjukkan bahwa terdapat 64\% peserta yang masih kurang mengetahui dan memahami tanda dan gejala awal penyakit demam berdarah Dengue. Selain itu sebagian besar peserta belum mengetahui cara melakukan pemeriksaan uji tourniquet. Setelah diberikan penyuluhan dan simulasi pemeriksaan uji tourniquet terjadi perubahan yang bermakna dimana para kader menjadi tahu dan paham tentang penyakit demam berdarah Dengue serta cara deteksi dini sederhana yang dapat dilakukan sebelum merujuk penderita ke tempat pelayanan kesehatan.
\end{abstract}

Kata kunci: DBD, tes tourniquet, kader kesehatan

Kasus penyakit demam berdarah Dengue (DBD) cenderung meningkat pada musim hu-jan karena terjadinya perubahan musim mempengaruhi frekuensi gigitan nyamuk. Perubahan musim itu sendiri mempengaruhi manusia terhadap gigitan nyamuk, dimana 
mereka akan cenderung lebih banyak berdiam dirumah selama musim hujan. ${ }^{1}$

Keterlambatan menegakkan diagnosis penyakit DBD sangat menentukan prognosis penderita. Semakin dini penyakit ini diketahui maka keberhasilan penanganan penderita semakin baik. Sebagian besar penderita DBD yang meninggal disebabkan oleh karena keterlambatan dirawat di rumah sakit. Gejala demam pada DBD hampir sama dengan demam oleh karena penyakit lain sehingga hal ini sering menyebabkan kesalahan dan keterlambatan dalam penanganan penderita DBD. ${ }^{2,3}$

Uji tourniquet merupakan salah satu cara untuk menegakkan diagnosis penyakit DBD, disamping pemeriksaan laboratorium darah. Uji tourniquet yang positif menunjukkan adanya suatu manifestasi perdarahan. ${ }^{3,4}$

Di Indonesia penyakit DBD pertama kali dilaporkan pada tahun 1968 di Surabaya dan Jakarta. Sejak itu angka kejadian penyakit DBD dilaporkan terus menigkat dengan angka kematian yang mencapai 10 $\%$ dari seluruh penderita yang dirawat di rumah sakit. Di Indonesia ditemukan 1.527 kematian dari 47.573 kasus pada tahun $1988 .^{3}$

Di provinsi Sulawesi Utara pada tahun 2000 terdapat 39 kasus kematian DBD dari 1105 kasus. Jumlah kasus terbanyak pada tahun 2000 yaitu di kotamadya Manado $82,3 \%$. Pada tahun 2003 terdapat tiga kasus kematian dari 286 penderita yang dilaporkan. Di kota Manado terjadi wabah DBD pada tahun 1974, yakni terdapat 700 kasus pada 150.000 penduduk. Rampengan (1983), menemukan 106 penderita DBD dengan 3,8\% mengalami kematian. Pada tahun 1993, terdapat 26 kasus DBD di kota Manado dengan dua orang meninggal. ${ }^{5}$

Kecamatan Malalayang adalah salah satu kecamatan yang terdapat di kota Manado yang terdiri dari delapan kelurahan dan merupakan daerah dengan angka kesakitan DBD yang tinggi. Kota Manado merupakan salah satu daerah endemis DBD karena jarak antar rumah yang berdekatan sehingga memudahkan penularan (jarak terbang nyamuk aedes aegypti $40-100 \mathrm{~m}) .{ }^{3,5}$
Kematian penyakit DBD seringkali terjadi oleh karena keterlambatan masyarakat awam dalam mengetahui diagnosis penyakit sehingga penderita terlambat dibawa ke tempat pelayanan kesehatan (rumah sakit, puskesmas, klinik, dokter praktek). Oleh karena itu perlu dilakukan pelatihan kepada masyarakat awam (non medis), dalam hal ini kader kesehatan. Diharapkan melalui kader kesehatan yang telah mengikuti penyuluhan dan dapat melakukan uji tourniquet, angka kematian akibat penyakit DBD dapat diturunkan. ${ }^{6,7}$

\section{TINJAUAN PUSTAKA}

Demam berdarah Dengue (DBD) adalah penyakit menular yang disebabkan oleh infeksi arbovirus (anthropod-borne virus) yaitu virus Dengue dan ditularkan oleh nyamuk aedes aegypti. Penyakit ini dapat menyerang semua orang dan dapat mengakibatkan kematian terutama anak-anak. Gejala utama DBD adalah demam, yang biasanya memburuk setelah dua hari pertama dan disertai beberapa atau semua gejala perdarahan spontan seperti petekie, ekimosis, purpura dan epistaksis. ${ }^{1,2}$

Epidemi demam Dengue dilaporkan pada sepanjang abad kesembilan belas dan awal abad keduapuluh di Amerika, Eropa Sela-tan, Afrika Utara, Mediterania Timur, Asia, Australia dan pada beberapa pulau di India, Pasifik Selatan dan Karibia. Pada tahun 1996 terdapat 2500-3000 juta orang yang potensial beresiko terhadap penularan virus dengue. Diperkirakan setiap tahun terdapat 20 juta kasus infeksi Dengue dan mengakibatkan sekitar 24 juta kematian. ${ }^{3,4}$

Penyakit DBD ditularkan oleh nyamuk aedes aegypti betina melalui gigitan pada orang yang mengandung virus dengue. Aedes aegypti ini bersifat antropofilik (senang sekali kepada manusia) dan biasa menggigit di dalam rumah, di luar rumah dan juga di tempat yang agak gelap. Nyamuk ini mempunyai kebiasaan menggigit berulang, yaitu menggigit beberapa orang secara bergantian dalam waktu singkat. Nyamuk betina dapat terbang sejauh $2 \mathrm{~km}$, tetapi kemampuan normalnya adalah 40 
meter. Nyamuk ini bersarang di bejanabejana yang berisi air jernih dan tawar seperti bak mandi, drum penampung air, kaleng bekas dan lainnya. ${ }^{1,3,5}$

Diagnosis DBD menurut WHO tahun 1975 adalah demam tinggi mendadak dan terus menerus selama 2-7 hari dengan sebab yang tidak jelas dan hampir tidak dapat dipengaruhi oleh antipiretik. Manifestasi perdarahan berupa uji tourniquet positif, spontan yaitu petekie, ekimosis, epistaksis, perdarahan gusi, hematemesis atau melena. Pembesaran hati dan syok yang ditandai dengan nadi lemah dan cepat sampai tak teraba (sampai nol). Tekanan darah menurun sampai nol disertai kulit yang teraba lembab dan dingin terutama pada ujung jari tangan, kaki dan hidung. Penderita menjadi lemah, gelisah sampai menurunnya kesadaran dan timbul sianosis disekitar mulut. Kriteria laboratorik yaitu trombositopenia dengan jumlah trombosit $\leq 10.000 / \mathrm{mm} 3$ dan hemokonsentrasi yaitu hematokrit/ Packed Cell Volume/PCV meningkat sebanyak $20 \%$. ${ }^{6,7}$

World Health Organization membagi DBD dalam empat derajat menurut beratnya penyakit DBD sebagai berikut:

- Derajat I: Demam disertai gejala tidak khas dengan satu-satunya manifestasi perdarahan adalah uji tourniquet positif.

- Derajat II: Derajat I di sertai perdarahan spontan di kulit dan atau perdarahan lain.

- Derajat III: Terdapat kegagalan sirkulasi yaitu nadi cepat dan lemah, tekanan nadi menurun atau hipotensi, kulit yang dingin dan lembab, serta penderita menjadi gelisah.

- Derajat IV: Renjatan/syok berat dengan nadi yang tidak teraba dan tekanan darah yang tidak terukur.

Derajat I dan II disebut demam berdarah Dengue (DBD) / Dengue Haemorrhagic Fever (DHF), sedangkan derajat III dan IV disebut DBD/DHF dengan renjatan atau Dengue Shock Syndrome (DSS). ${ }^{8-10}$

\section{TUJUAN PENELITIAN}

Kegiatan penelitian ini bertujuan untuk melatih para kader kesehatan di desa, agar para kader ini dapat turut membantu dalam penanganan dan diagnosis dini penderita DBD agar tidak jatuh ke dalam Dengue shock syndrome (DSS). Kader kesehatan dapat membantu tenaga medis agar penderita yang demam dan terdiagnosis uji tes tourniquet positif sesegera mungkin untuk dirujuk dan dirawat di pelayanan kesehatan/rumah sakit. Hal ini dapat mencegah akibat buruk yang fatal yaitu kematian penderita DBD karena terlambat di bawa ke tempat pelayanan kesehatan, terutama rumah sakit.

\section{METODE PENELITIAN}

Metode kegiatan dalam pelatihan ini adalah pemberian ceramah/penyuluhan tentang penyakit DBD serta simulasi dan manfaat dari pelatihan uji tourniquet. Para kader kesehatan diharapkan dapat mendeteksi secara dini penyakit DBD dan dengan secepatnya merujuk pasien ke rumah sakit setelah uji tourniquet positif sehingga dapat mencegah kematian penderita DBD

Untuk mengukur keberhasilan pelaksanaan pelatihan ini dilaksanakan evaluasi dengan cara :

1. Memberikan evaluasi mengenai beberapa teori kepada para peserta untuk mengetahui sampai sejauh mana penerimaan dan pengertian peserta tentang penyakit DBD.

2. Praktek atau simulasi cara pemeriksaan uji tourniquet, yang sebelumnya telah diajarkan cara pengukuran tekanan darah kemudian uji tourniquet.

3. Evaluasi akhir dengan mengamati peserta menerapkan cara pemeriksaan uji tourniquet sebagai salah satu diagnosis dini penyakit DBD.

\section{HASIL DAN PEMBAHASAN}

Dilakukan kegiatan pengabdian kepada masyarakat dalam bentuk pelatihan pemeriksaan uji tourniquet kepada kader kesehatan di Kecamatan Malalayang. Pelatihan ini diikuti oleh kader kesehatan dari seluruh desa yang terdapat pada delapan kelurahan 
di Kecamatan Malalayang. Masing-masing kelurahan diwakili oleh tiga orang kader kesehatan untuk mengikuti pelatihan ini. Kader kesehatan yang hadir untuk mendapatkan pengetahuan serta keterampilan untuk melakukan pemeriksaan uji tourniquet sebanyak 25 orang. Pelatihan berlangsung selama satu hari dan dilaksanakan pada bulan Mei 2008 bertempat di Puskesmas Bahu Kecamatan Malalayang.

Pelaksanaan pelatihan dimulai dengan metode tatap muka dalam bentuk ceramah tentang: "Penyakit DBD dan deteksi dini dengan uji tourniquet". Dilakukan test evaluasi awal kepada peserta untuk mengetahui pengetahuan mereka tentang penyakit DBD yaitu tanda dan gejala serta cara praktis untuk mengetahui secara dini penyakit DBD. Kemudian dilanjutkan dengan simulasi/praktek melakukan pemeriksaan uji tourniquet diantara sesama peserta pelatihan.

Peserta pelatihan terdiri dari 25 orang dan hampir semua (96\%) yang hadir adalah jenis kelamin perempuan. Hal ini menunjukkan bahwa kepedulian terhadap pentingnya mengetahui deteksi dini penyakit DBD pada khususnya dan masalah kesehatan pada umumnya lebih diperhatikan oleh kelompok perempuan. Perempuan dalam status keluarga adalah ibu rumah tangga yang biasanya bertanggung jawab mengurus anak-anak dalam keluarga, termasuk kesehatannya. Hal ini yang mungkin menyebabkan sebagian besar tenaga sukarela dari masyarakat yang bersedia menjadi kader kesehatan biasanya adalah perempuan.

Kelompok umur terbanyak kader kesehatan Kecamatan Malalayang adalah 30-39 tahun (44\%), diikuti kelompok umur 40-49 tahun (32\%), kelompok umur 20-29 tahun (16\%), dan kelompok umur 50-60 tahun $(8 \%)$. Berdasarkan karakteristik umur kader kese-hatan di Kecamatan Malalayang sebagian besar masih dalam kelompok usia produktif dan energik. Kondisi ini sangat membantu program kesehatan karena yang menjadi kader kesehatan adalah kelompok usia yang masih kuat dan sehat serta berpotensi, yang pada akhirnya bisa bersama-sama membantu dan menunjang me- ningkatkan derajat kesehatan pada umumnya.

Berdasarkan hasil evaluasi awal (pretest) para peserta, diperoleh bahwa sebagian besar, yaitu 23 orang peserta $(92 \%)$ sudah mengetahui penyakit DBD adalah penyakit yang berbahaya dan dapat berakibat fatal yaitu kematian. Hal ini merupakan hasil yang sangat baik karena ternyata hampir semua kader kesehatan di Kecamatan Malalayang telah mempunyai pengetahuan yang baik tentang penyakit DBD. Sebagian besar telah mengetahui bahwa penyakit DBD itu adalah penyakit yang didahului dengan demam, dan jika tidak ditangani secara serius dapat berakibat fatal yaitu kematian. Namun setelah ditanyakan tentang gejala-gejala lainnya, sebagian besar masih belum tahu secara pasti. Hal ini dapat dimaklumi karena menjadi kader kesehatan di masyarakat adalah murni bukan orang medis atau berprofesi kesehatan. Keluhan dan gejala penyakit DBD dpat bervariasi, bahkan kadangkala gejala yang ditimbulkan tidak khas untuk DBD. Gejala panas/demam itu sendiri bisa disebabkan oleh berbagai macam penyebab penyakit lainnya seperti gejala flu (common cold) biasa, radang tenggorokan (tonsillopharyngitis), demam malaria, demam typhoid, dan lain sebagainya. Tak jarang terjadi kesalahan diagnosis karena penyakit-penyakit tersebut menunjukkan gejala awal yang sama yaitu demam. ${ }^{3,6-8}$ Perlu diperhatikan bahwa pada pasien DBD perlu dilakukan tindakan pengobatan yang sesegera mungkin; jika terlambat dapat menyebabkan komplikasi yang pada akhirnya tidak dapat dikendalikan lagi dan berakibat kematian. ${ }^{2,4,5,11}$

Peserta yang masih kurang mengetahui dan memahami tanda dan gejala awal penyakit DBD terdapat 16 orang $(64 \%)$. Hal ini menunjukkan bahwa masih banyak kader kesehatan yang belum memahami secara pasti gejala dan tanda bagaimana yang harus segera ditangani secara serius, dengan kata lain pasien harus segera dibawa ke tempat pelayanan kesehatan (Puskesmas/ Rumah Sakit/Klinik) terdekat. Apabila panas sudah berlangsung selama tiga hari berturut-turut dan menunjukkan gejala 
perdarahan yang lain, sudah harus secepatnya dilakukan tindakan lanjut yaitu pemeriksaan penunjang lainnya seperti uji tourniquet dan pemeriksaan laboratorium darah tepi (trom-bosit dan hematokrit) Bila uji tourniquet (+) dan pemeriksaan laboratorium darah tepi trombosit menurun dan hematokrit meningkat, maka pasien harus secepatnya dirawat di rumah sakit. ${ }^{9,10}$

Kegiatan ini dilakukan untuk mencegah terjadinya keterlambatan pertolongan kepada pasien DBD agar tidak menjadi DSS (Dengue Shock Syndrome). Apabila pasien DBD yang sudah lanjut dan telah terjun menjadi DSS, maka kemungkinan untuk sembuh sangat kecil. Untuk itu pada kegiatan ini diberikan pelatihan uji tourniquet bagi orang awam dalam hal ini masyarakat (kader kesehatan) agar mereka dapat membantu penjaringan pasien dengan gejala DBD secara dini untuk menurunkan kejadian kematian akibat penyakit DBD-DSS.

Sebagian besar $(96 \%)$ peserta pelatihan atau kader kesehatan yang ada di Kecamatan Malalayang masih belum mengetahui apa itu uji tourniquet dan hanya satu orang $(4,0 \%)$ yang mengetahui uji tourniquet positif merupakan salah satu petunjuk untuk menentukan diagnosis dini penyakit DBD. Ternyata dari semua kader kesehatan di Kecamatan Malalayang hanya terdapat satu orang kader yang mengetahui bahwa uji tourniquet merupakan salah satu cara untuk mendiagnosis DBD.

Sedangkan mengenai cara melakuakn pemeriksaan uji tourniquet, ternyata semua peserta tidak mengetahui cara melakukannya. Hal ini menunjukkan bahwa ternyata pelatihan uji tourniquet ini sangat diperlukan. Lagipula meskipun pemeriksaan ini merupakan salah satu pemeriksaan yang sangat sederhana namun dapat dipakai sebagai acuan untuk menambah kecurigaan adanya DBD. Dengan demikian harus secepatnya membawa pasien demam yang dicurigai sebagai pasien DBD ke tempat pelayanan kesehatan (puskesmas/rumah sakit/ klinik/dokter praktek) terdekat.

Selanjutnya dilakukan simulasi/praktek kepada peserta pelatihan, setelah di berikan contoh untuk melakukan pemeriksaan uji tourniquet. Masing-masing peserta melakukan pemeriksaan uji tourniquet secara bergantian dengan temannya sampai masingmasing peserta tahu dan bisa melakukannya sendiri. Setelah di evaluasi akhir, semua peserta pelatihan dapat melakukan uji tourniquet dengan baik.

Akhir pelatihan diberikan secara cumacuma alat tensimeter dan stetoskop untuk membantu para kader dalam melakukan uji tourniquet di lingkungannya masingmasing. Terdapat delapan kelurahan di Kecamatan Malalayang, maka diberikan satu set alat pemeriksaan uji tourniquet untuk masing-masing kader di delapan kelurahan tersebut.

\section{KESIMPULAN}

1. Sebagian besar peserta pelatihan di Kecamatan Malalayang sudah mengetahui bahwa penyakit DBD adalah penyakit yang berbahaya dan dapat berakibat fatal yaitu kematian.

2. Sebagian peserta pelatihan di Kecamatan Malalayang masih kurang mengetahui dan memahami tanda dan gejala awal penyakit DBD.

3. Sebelum dilakukan pelatihan sebagian besar peserta pelatihan di Kecamatan Malalayang masih belum mengetahui cara melakukan dan memanfaatkan uji tourniquet.

4. Setelah dilaksanakan pelatihan semua peserta pelatihan di Kecamatan Malalayang dapat melakukan uji tourniquet dengan baik

\section{SARAN}

1. Diperlukan penyuluhan tentang bahaya penyakit DBD kepada masyarakat umum, agar dapat mencegah kematian akibat penyakit DBD.

2. Diperlukan sosialisasi pelatihan uji tourniquet kepada masyarakat yang lebih luas, agar dengan alat bantu yang sederhana ini dapat dilakukan deteksi dini DBD, dan dengan demikian dapat mengurangi kemungkinan terjadinya akibat buruk DSS. 
3. Diperlukan pemberian alat pemeriksaan tensimeter dan stetoskop secara gratis untuk membantu masyarakat dalam melakukan deteksi dini DBD dengan uji tourniquet.

\section{DAFTAR PUSTAKA}

1. Ginanjar G. DBD. A survival guide. Mizan Media Utama. Bandung, 2008.

2. Departemen Kesehatan RI Ditjen PPM \& PL. Pencegahan dan penanggulangan penyakit demam dengue dan DBD dengue. Edisi Tahun 2003. Depkes RI Ditjen PPM \& PL, 2003.

3. Departemen Kesehatan RI Sub Direktorat Arbovirus. Epidemiologi dan penanggulangan DBD saat ini di Indonesia. Jakarta: Depkes RI, 2001.

4. Rampengan TH, Laurentz IR. Penyakit Infeksi tropik pada anak. Cetakan III. Jakarta: EGC, 1997.

5. Dinas Kesehatan Propinsi Sulawesi Utara.
Masalah DBD dengue di Propinsi Sulawesi Utara, 2003.

6. Departemen Kesehatan RI, IDAI, PAPDI, dkk. Penatalaksanaan kasus DBD dengue (DBD). Jakarta, 2004.

7. Hastuti Oktri. DBD Dengue, penyakit dan cara pencegahannya. Yogyakarta: Penerbit Kanisius, 2008.

8. Monath P. Flavivirus (yellow fever, dengue, and St. Louis encephalitis) dalam: Mandell, Douglas, Bennet. Principles and Practice of Infectious Diseases. Third Edition, 1990.

9. Nadesul Hendrawan. Cara mudah mengalahkan DBD. Jakarta: Penerbit Buku Kompas, 2007.

10. World Health Organization. Dengue haemorrhagic fever. Geneva: Diagnosis, Treatment, Prevention and Control) WHO, 1997.

11. Sukarno. Pengendalian jentik nyamuk vektor DBD. Buletin Penelitian Kesehatan, 2000. 